obtained from desoxybenzoïn, by united oxidation and treatment with alcoholic potash, a peculiar body, $\mathrm{C}_{70} \mathrm{H}_{56} \mathrm{O}_{4}$, to which he gave the name of benzamarone, and which he decomposed into desoxybenzoin and amaric acid, $\mathrm{C}_{46} \mathrm{H}_{42} \mathrm{O}_{6}$. This latter he decomposed, in 1877 , into benzoic acid and so-called pyroamaric acid. Various homologues were obtained by varying the alcohol used as a solvent for the potash, and pyroamaric acid was shown to be a benzyl-ethyl-benzoic acid. One of his later investigations showed the peculiar property possessed by zinc of regenerating hydrocarbons from the solutions of their addition compounds by extracting the halogens from the latter.

The researches published by Zinin during the latter portion of his career, while marked by careful study and minute elaboration, lack much of that originality and generality of application characteristic of his earlier discoveries. As contributions to the development of the use of reducing agents in organic chemistry, they occupy, however, an important place in the annals of the science, while the cissemble of reactions and derivatives of the benzoin group forms one of the important sections of the chemistry of the aromatic series.

Prof. Zinin's merits were warmly appreciated in his own country, and he was the recipient of numerous decorations, some of which were due to the important services rendered by him in the solution of questions connected with the Russian military department. In 1855 he was elected to the Imperial Academy of Sciences at St. Petersburg. He was the only Russian among the corresponding members of the Chemical Section of the French Academy of Sciences, and was likewise one of the few honorary members of the London Chemical Society and of the German Chemical Society.

T. H. N.

\section{WILHELM PHILIPP SCHIMPER}

PROF. SCHIMPER, to whose death at Strassburg on March 20 we have already alluded, was one of the most prominent scientific men in Alsace. He was born, January 8,1808 , at Dosenheim, near Elsass-Zabern. After taking a course of theological studies at the University of Strassburg, he devoted his attention to natural history. A period of travel was succeeded by his appointment in 1835 as assistant in the Natural History Museum at Strassburg. In 1839 he became director of the establishment, and was elected Professor of Geology and Mineralogy in the University. Before this date he had already attracted attention in the botanical world by his studies on mosses, and he soon became one of the leading authorities on this branch. A monument of his work as a specialist is left in his famous "Bryologia Europæa," which appeared in six volumes with 640 plates, from 1836 to 1855 ; and was provided with an extensive supplement in 1866. Other well-known important works in this connection are his "Recherches anatomiques et morphologiques sur les Mousses " (1850), "Mémoire pour servir à 1 histoire Naturelle des Sphagnum" (1854), and "Synopsis muscorum europæorum" (1860; 2nd edit. 1876). As a palæontologist Schimper has produced-1869-1874-a "Traité de Paléontologie végétale," in three volumes, which ranks among the best text-books on the subject. Much of his attention and time was directed to the rich fossil remains of Alsace itself, and it is to these studies that we owe the valuable monographs, "Plantes fossiles des Vosges," written in 1844 in connection with A. Mougeot; "Palæontologica Alsatica" (1854); and "Le Terrain de transition des Vosges"(I862). The marked talent for botany in the Schimper family is something unusual ; Prof. Schimper's two cousins having gained, like himself, honoured places in the annals of the science. Karl Schimper, who taught at Munich and Heidelberg, and died in 1867 , was distinguished as the founder of the modern theory on the position of leaves, so ably expanded by the late Prof. Braun; while Wilhelm Schimper has widely increased our knowledge of African flora by his researches in Abyssinia, where he was released from imprisonment by the English expedition in 1868 .

\section{NOTES}

MM. W. De Fonvielle and D. Lontin described to the Paris Academy last week a magnetic gyroscope, the object of which is to give a movement of rotation to movable pieces of soft iron of various forms. M. de Fonvielle is at present in London with the apparatus, from which some very curious results have been obtained. We hope to give a full account of the invention, with illustrations, in our next number.

M. B. BRUNET has presented the sum of 20,000 francs to the French Association for the Advancement of Science, the interest to be distributed annually for the promotion of scientific research.

AmoNG recent deaths announced are those of Dr. Joh. Eman. Zellerstedt, the Swedish bryologist; Dr. M. A. F. Prestel, of Emden, the meteorologist ; and Dr. Mulder Bosyoed, of Rotterdam, author of a "Bibliotheca ichthyologica et piscatoria."

THE French Academy of Sciences numbers seventy-eight. At present two seats are vacant: one in the section of mechanics and one in that of geography and navigation. The number of foreign associates and corresponding members allowed by the statutes is 108. There are now four vacancies: two in the ehemical section, one in the botanical, and one in that of geography and navigation. The classification of this portion of the Academy by nationalities affords an interesting view of the judgment of Parisian scientific men on their confreres according to "geographical distribution." France, outside of Paris, heads the list with 30 members; then follow Great Britain, 21; Germany, I7; United States, 8; Russia, 6; Switzerland, 6; Scandinavian countres, 5; Italy, 4; Belgium and Holland, 4; Austria, 2, and Brazil, I.

IN a letter in yesterday's Times, deserving the serious attention of those in authority, Mr. Merrifield strongly advocates the appointment of an independent commission for inquiry into the whole question of the construction of our heavy guns. Mr. Merrifield seeks to show that the system at present in use is accompanied with the most serious disadvantages.

A prospectus has been issued by the Wilts and Hants Agricultural College, of which we spoke last week. Every arrangement has apparently been made for the improvement and comfort of students,

In a paper in the Fournal of the Royal Society of New South Wales, on the Forests of Tasmania, by the Rev. J. E. Tenison Woods, the author gives some interesting data as to the probable age of the stately trees which people these forests. Judging from their size one would be inclined to attribute to them great antiquity. Mr. Woods was very anxious to collect data on the subject; but to nearly all his inquiries he only received mere guesses: from 200 to 300 years was the general reply. Mr. R. Hill, the proprietor of an extensive saw-mill at Honeywood, on the Huon, gave him, however, some more trustworthy data. Mr. Hill assured $\mathrm{Mr}$. Wood that some of the gum-trees, and perhaps all of them, shed their bark twice in the year. The stringy bark ( $E$. oblizua) is one of the most striking instances of this. He further informed Mr. Woods that, hearing a lecture from Mr. Bicheno on the growth of trees, and the statement that a ring of wood was added to the diameter each year of growth, he was induced to test the truth of this. There was a blue gum-tree in his garden in Hobart Town, the age of which he was sure of, as his brother had planted it eighteen years previously. He felled it and counted the rings, and found them to be thirty-six in number, or 